\title{
INVENTANDO TEMPOS OUTROS COM BERGSON E DELEUZE EM COLETIVOS ESCOLARES: A POTÊNCIA DA IMAGEM-MOVIMENTO E DA IMAGEM-TEMPO NAS PRODUÇÕES CURRICULARES
}

\author{
Janete Magalhães Carvalho ${ }^{1}$ \\ Steferson Zanoni Roseiro ${ }^{2}$
}

\begin{abstract}
Resumo
$\mathrm{O}$ artigo objetiva, a partir de problematizações estabelecidas em redes de conversações no encontro entre professores $e$ imagens filmicas, discutir os conceitos de tempo vivido, afetivo, e percebido. Tomando como intercessores teóricos Bergson e Deleuze, aposta no uso de imagens filmicas (imagemmovimento e imagem-tempo) como disparadora de modos mais potentes de viver as tramas do tempo no cotidiano escolar e, nesse sentido, enfoca a imagem como máquina de pensar.
\end{abstract}

Palavras-chave: Cinema. Imagens filmicas. Produção curricular. Imagemmovimento. Imagem-tempo.

\section{Resumen}

El trabajo tiene como objetivo, desde problematizaciones establecidas en redes de conversaciones en el encuentro entre los maestros y imágenes de películas, debater los conceptos de tempo vivido, afectivo y percebido. Teniendo como intercesores teóricos Bergson y Deleuze, apuesta por el uso de imágenes de películas (imagenmovimiento y imagen-tiempo) como el causante de las formas más poderosas de vivir los marcos de tempo em la vida escolar cotidiana y, em consecuencia, se enfoca la imagen como una máquina de pensar.

Palabras clave: Cine. Imágenes de películas. Producción curricular. Imagenmovimiento. Imagen-tiempo.

\section{Para início de conversa}

Que tempos se fazem presentes nos cotidianos escolares? Tempos rígidos, tempos inventivos, tempos de fuga, tempos escolarizados? Quais tempos nos

\footnotetext{
1 Professora do Departamento de Educação, Política e Sociedade e do Programa de PósGraduação em Educação da Universidade Federal do Espírito Santo. Conato: janetemc@terra.com.br

${ }^{2}$ Graduando em Pedagogia pela Universidade Federal do Espírito Santo e bolsista de Iniciação Científica pela CNPq. Contato: zanoniroseiro@hotmail.com
}

CARVALHO, Janete Magalhães; ROSEIRO, Steferson Zanoni. Inventando tempos outros com Bergson e Deleuze em coletivos escolares: a potência da imagemmovimento e da imagem-tempo nas produções curriculares. Revista Sul-Americana de Filosofia e Educação. Número 25: nov/2015 - abril/2016, p. 83-96. 
afetam quando entramos os portões das escolas? Como outros tempos atravessam essas instituições e neles são percebidos?

Este artigo objetiva, a partir de problematizações decorrentes do processo de pesquisa com professores de escolas públicas de ensino fundamental, utilizando o cinema, relacionar o tempo vivido, afetivo e percebido no cotidiano escolar com osconceitos de imagem-movimento e imagem-tempo, em sua composição como "clichês" e como possíveis "cristais do tempo".

Como intercessores teóricos privilegiados deste trabalho, adotamos as contribuições de Bergson (2006) e Deleuze (1985, 1990) focando, como dito, a questão do TEMPO em sua relação com a potência das imagens fílmicas nas redes de conversações de professores em suas problematizações dos tempos escolares.

A pesquisa foi realizada no ano de 2013, em duas escolas da Rede Municipal de Educação de Vitória/ES, utilizando, como estratégia metodológica, a pesquisa-intervenção em redes de conversações (CARVALHO, 2009) com o coletivo de professores das escolas, em reuniões quinzenais, tendo, como elemento provocador das problematizações e possíveis ações decorrentes, o cinema.

Foram problematizados, a partir das imagens cinematográficas, sete filmes, discutindo-se, a partir deles, as produções curriculares que atravessam o corpo coletivo escolar. Os filmes escolhidos para as redes de conversações foram: 1) Um raio de Sol através da chuva, primeiro episódio do filme Sonhos (1990), de Akira Kurosawa; 2) Frat (2008), um curta-metragem de Sebastien Durand; 3) Bilu e João, de Katia Lund, do longa Crianças invisíveis (2005); 4) Tanza, outro episódio do filme Crianças invisíveis, sob a direção de Mehdi Charef; 5) Somos todos diferentes (2007), do diretor e ator Aamir Khan; 6) O vendedor de fumaça (2013), criado por estudantes da Escola de Arte PrimerFrame; e 7) Stella (2008), de Sylvie Verheyde.

Esses filmes selecionados (longas e curtas-metragens) propiciaram uma rica rede de enunciados discursivos referentes a problemas que se fazem presentes nos cotidianos escolares apresentados nessas redes, destacando-se o tempo. Nas redes de conversações com os professores, os tempos foram apontados como tempos rígidos, hierarquizados, de organização, enfim como tempos que suscitam a 
passividade e/ou a não resistência; mas fomos, também, atravessados com enunciados que apresentaram outras percepções e usos dos tempos escolares, que não apenas resistem, mas fazem usos desterritorializantes dos tempos científicos e/ou cronológicos.

Nas redes de conversações, os enunciados diziam de tempos que arriscavam potência de criação, de composição de outras práticas, fazendo submergir lógicas periodizadas - a própria organização dos grupos e a nossa presença ali se faziam nessas tramas nas quais o Tempo (científico, metodológico, cronológico) era subvertido em outros tempos: tempos plurais e heterogêneos.

Assim, discutir os tempos e seus usos nos ambientes escolares mostrou-se um aspecto relevante, considerando as problematizações desencadeadas pelos professores nos encontros nas escolas da pesquisa, visto que, ao colocarem suas indagações, falavam de tempo em diferentes concepções, atravessando tanto os tempos pontuais/quantitativos contrapostos por Bergson (apud GUERÓN, 2011) quanto os tempos que se fazem durações, os tempos qualitativos (DELEUZE, 2012). Professores que, no cotidiano escolar, falam desses tempos que são capazes de endurecer as práticas escolares, mas que são também capazes de encontrar linhas que atravessam esse tempo molar com força o suficiente para fazê-lo um tempo molecular, um tempo que reaviva devires.

\section{Os tempos mortos?}

Pensar a problemática do tempo a partir da concepção de Bergson implica questionar a cientificidade deste. Ao se falar de tempo para a ciência, cria-se uma expectativa matemática, de tempo como algo quantificável, passível de contabilização e de objetivação (DELEUZE, 2012). Como comumente discutido pela Física, o tempo, nessa vertente, é um duo do espaço, espaço esse que "[...] introduz a forma de suas distinções extrínsecas ou de seus 'cortes' homogêneos $e$ descontínuos" (DELEUZE, 2012, p. 31).

Cria-se, para a ciência, um tempo que é objetivo e, portanto, pode ser sequencial e interrompido, atuando sob uma lógica de que, se interrompido - se o 
cronômetro for parado, por exemplo - basta, depois, retornar ao ponto em que se encontrava.

Guerón (2011) discute o tempo ao qual Bergson se contrapõe, colocando-o no mesmo lugar em que se encontra o movimento, visto que, para a Física, o movimento e o tempo podem sempre ser compreendidos a partir de instantes pontuais que, juntos, compõem retas, retas essas que, acredita-se, são capazes de reproduzir os movimentos e o tempo. Assim, Bergson contrapõe-se a esse primeiro postulado: ao pontificar o tempo e o movimento, ao tentar reter algo que é, naturalmente, fluido, livre, incessante e móvel, ocorre um assassinato - "[...] por mais que aumentemos esses pontos indefinidamente, o movimento se dará sempre antes ou depois, e nunca neles" (GUÉRON, 2011, p. 70).

Sob essa ótica de tempo factível a cortes que podem ser descontínuos, por exemplo, encontramos a organização escolar que vivenciamos: aulas que são pautadas de 50 em 50 minutos, interrompidas como se pudessem retornar na semana seguinte sem nenhuma alteração; tempos que são insuficientes para a realização das atividades; tempos que se perdem e que fazem os encontros se perderem. Esses são alguns dos exemplos que emergem nas trajetórias do fazerdocente: "O tempo cronometrado atropela o existencial $e$ as possibilidades de aprendizagens significativas. Muitos momentos de discussão são perdidos ou adiados por não ser o tempo ou espaço 'apropriados"; " $A$ falta de tempo hábil para o planejamento nos remete a práticas de um simples 'seguir os encaminhamentos' propostos pelos livros didáticos"; " O professor não tem tempo necessário para abrir o currículo"; "O horário preestabelecido em frente a um currículo hierarquizado inviabiliza qualquer processo democrático de aprendizagem, pois a sala de aula apresenta diferentes níveis de aprendizagem"; "O horário escolar hierarquizado impede o desenvolvimento da criatividade. O aluno é pouco ouvido e participa pouco da produção do currículo".

Vemos, nessas falas, o quanto as problemáticas lançadas ao tempo são amplas - questionam os usos que se fazem desses tempos numéricos que apresentam uma pseudorreversibilidade, como algo que permite uma correção do passado. $\mathrm{O}$ "[...] erro é acreditar que com todos estes esquemas recomporíamos o 
real" (BERGSON, apud AZAMBUJA, 2009, p. 4). Quando professores questionam os tempos que lhes são negados (negados aos próprios docentes, aos discentes, enfim, à vida na/da escola), podemos/devemos ver esses questionamentos como falas que lançam perguntas a um tempo soberano e soberbo, pontuando que esse tempo cronológico não é possível de vivenciar.

O tempo organizacional, prisioneiro do espaço (COELHO, 2004) - um tempo que é apenas quantitativo - faz-se, principalmente, como afirmação científico-matemática do espaço. Um tempo que só se faz perceptível pelo que lhe é exterior - não se tem tempo para "abrir" o currículo porque 50 minutos de planejamento espalhados pelos cinco dias da semana são tão quebrados quanto as próprias aula; tempos que atropelam porque aquela sala será utilizada no próximo minuto. "Toda vez que a gente chega, a gente olha o quadro. O pessoal da manhã faz assim: olha o quadro e cadê? Onde que eu vou, qual a reunião, qual a tarefa, qual é a coisa que eu tenho que seguir? O tempo é muito comprimido. E às vezes chega a essa época do ano, outubro e novembro, que a gente já está tão assim... 'acaba logo". Em suma, um tempo que existe apenas se conjugado a outra coisa. É, inclusive, por essa concepção de tempo aprisionado a outros liames que Deleuze faz dos estudos de Bergson uma base para seu conceito de diferença.

Trançando falas docentes com esse tempo mecanizado, somos levados a pensar nos espaços que são destinados a tempos - sala de aula, tempo de estudar/ensinar; pátio, tempo de brincar; sala dos professores, tempo para planejar... tempo que não se permite ser múltiplo. Como Bergson define: esse é um tempo que não é divisível porque, ao ser dividido, ele se diz ainda o mesmo. Uma pretensão que não lhe é possível - tempo faz-se unicamente divisível quando se permite ser múltiplo; tempos são divisíveis, é duração que se divide

[...] e não para de dividir-se: eis por que ela é uma multiplicidade. Mas ela não se divide sem mudar de natureza; muda de natureza, dividindo-se: eis por que ela é uma multiplicidade não numérica, na qual, a cada estágio da divisão, pode-se falar de 'indivisíveis' (DELEUZE, 2012, p. 36). 
Enfim, esse tempo mecânico é o tempo o qual Bergson nega - tempo que é objeto/objetivo e que, portanto, é apenas atual, no sentido de não ter virtualidade (DELEUZE, 2012, p. 34).

[...] a matéria não tem nem virtualidade nem potência oculta, pelo que podemos identíficá-la com a 'imagem'; sem dúvida, pode haver mais na matéria do que na imagem que dela fazemos, mas não pode haver nela outra coisa, algo de natureza distinta.

Assim, pensando com os filmes que apresentamos, nossa intenção não é responder que concepção de tempo as narrativas cinematográficas apresentam, mas pensar como essas imagens podem fazer cintilar problematizações que potencializem tanto os tempos produzidos nas escolas, como o agenciamento do desejo dos professores que desestabilizem experiências organizadas por esquemas sensório-motores - clichês.

\section{Um close nas imagens: deslizando por entre problematizações com os filmes}

Ao questionarmos com os professores esse tempo objetivo, esse tempo que não é duração, tangenciamos as concepções da imagem em Deleuze: imagemmovimento e imagem-tempo e, nestas, a imagem-cristal (DELEUZE, 1985, 1990). Ainda que o tempo seja o que diferencia essas duas formas de produção de cinema, Deleuze, em sua obra, discute, com base em Bergson (2006), a relação entre imagem, movimento e tempo, desenvolvendo o conceito de imagem (percepção, afecção e ação) que o cinema trabalha.

Dessa forma, precisamos perguntar: o que é a imagem? Como percebemos as imagens? Para a razão científica moderna, um objeto não pode se perceber por si mesmo. Com base na filosofia de Platão e nos postulados de Descartes, as forças advindas do corpo e das paixões, ou de quaisquer interesses sensíveis, tensionariam o pensamento para uma percepção falsa, impossibilitando enxergar a imagem como luminosidade pura (SCHÖPKE, 2004). Ao colocar que uma percepção pode ser errônea, porque, caso uma pessoa se deixe afetar por razões sensíveis não poderá enxergar a imagem pura, a forma real de algo - lógica essa que fundamenta todo o movimento iluminista - nessa perspectiva, acredita-se ser 
preciso se valer de uma razão pura para que possamos iluminar as coisas e, então, perceber a realidade como ela é.

Em contraposição, Bergson afirma que todos os corpos e todas as imagens são luminosos, não é necessária a existência de uma luz transcendental que faça com que objetos/imagens/corpos saiam da escuridão. Eles se iluminam porque estão em movimento - "a imagem é a expressão do movimento" (GUÉRON, 2011, p. 70) - e, ao se movimentarem, as imagens se fazem perceptíveis.

Machado (2010), citando Deleuze, diz que toda a fotografia é antecedida por outra fotografia - ela já foi capturada antes de a máquina realizar seu instantâneo, por outros corpos, outras imagens, outros objetos. Isso porque, para Bergson, as imagens não apenas se movem e são iluminadas, elas também se percebem e são percebidas. Essas imagens/corpos/objetos que compõem o universo são chamadas de imagens-movimento (MACHADO, 2010) ou objetosimagem (GUÉRON, 2011).

Ao falar da captura da câmera fotográfica, portanto, estamos falando de uma percepção de objetos-imagem que são capazes de perceber outros objetosimagem - e não apenas capazes, porque essa percepção é incessante. Desse modo, os corpos se percebem, percebem seus arredores e são também projetados sobre outros. Todavia, esse contínuo ato de se perceberem não implica a criação do material fotográfico, por assim dizer, em que as percepções são acentradas. Para que haja a criação da fotografia, por exemplo, é preciso que haja um material papel fotográfico, rolo de filme, memória virtual - onde a imagem passa a ser retida. Para Bergson, os corpos capazes de reter esses movimentos, de percebê-los e criar uma espécie de atraso na percepção, são chamados de imagem-viva ou de centro de indeterminação.

Essa percepção, entretanto, não ocorre ao acaso e sequer é capaz de perceber e reter todos os movimentos; a retenção das imagens é selecionada de acordo com o que Guerón (2011, p. 78) chama de percepção subjetiva:

Quando escolhemos o que vamos perceber, estamos escolhendo com o que vamos interagir. $O$ que há nesse momento é uma ação imediata e também uma retenção, quer dizer, um movimento que se interioriza $e$ vai 
constituindo a memória. A memória para Bergson é, então, uma retenção de movimento que, quando evocado por um movimento sofrido pelo corpo no presente (a percepção) literalmente se reincorporará: irá se reapresentar no limite entre memória e matéria (entre passado e futuro), que vem a ser o próprio corpo.

Pensando assim, na percepção dos movimentos, trazemos para discussão os filmes escolhidos para nossa pesquisa. Se não há como pensar em percepção dissociada da memória e nem em memória que não seja evocada por uma percepção (no) presente, o que propomos aqui não é apresentar uma síntese dos filmes assistidos, mas tentar elucidar as provocações temporais que se fazem presentes nos filmes assistidos no coletivo.

Imagem 1 - Stella (2008)

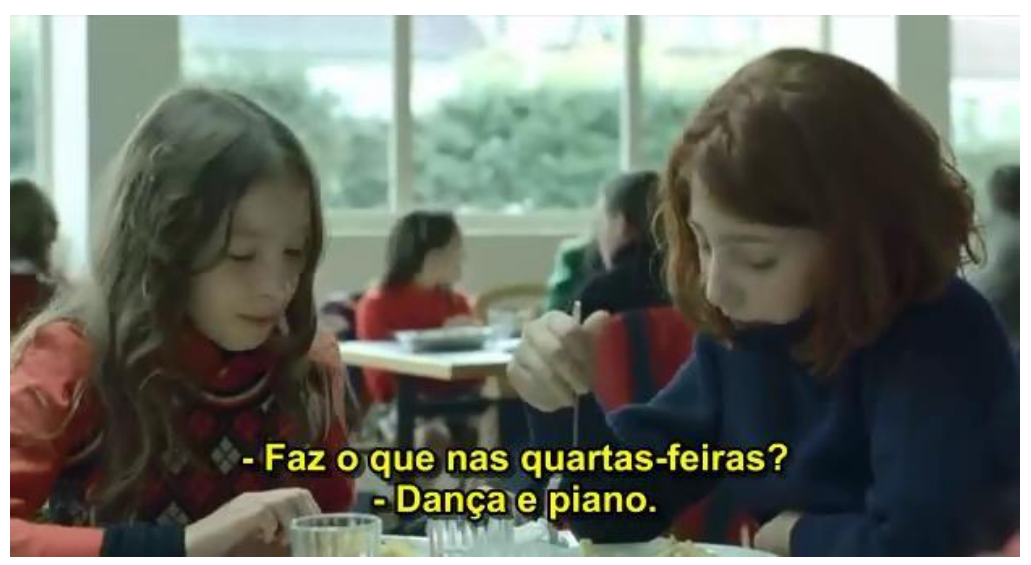

Fonte: Filme Stella

"Os interesses dos alunos tendem a não ser os tratados nos livros didáticos e nas aulas expositivas dos professores,"

No filme Stella (2008), a grande problemática que se faz presente é relacionada com a infância, o tempo de se fazer criança que, a todo momento, parece ser roubado, descontado, (sub)traído, enganado. Na Imagem 1, por exemplo, os tempos discutidos são tempos cronologizados que passam a roubar da menina o tempo de ser criança (a ela é imposta a realização de atividades pelas quais não tem interesse, mantendo-a ocupada, com uma agenda cheia) e, ainda assim, provocando na protagonista (Stella) a necessidade de criar para si uma rota 
de fuga. No filme, constantemente, vemos Stella pensando em coisas que ela não conhece, coisas que não sabe, e a escola parece-lhe um local em que seu tempo é sempre mal utilizado: ela poderia estar no bar ajudando sua mãe ou talvez ficando mais amiga dos amigos de seus pais ou simplesmente dançando, sorrindo, pulando...

Também esses tempos roubados são questionados com o episódio de Bilu $e$ João, do filme Crianças invisíveis (2005). Diferentemente do filme Stella, entretanto, as imagens dos irmãos que perambulam pelas ruas apontam para formas mais potentes de existir. Tempos que são atravessados por paixões tristes, mas que evocam nos professores movimentos de (re)existências - professores que passam a contar suas histórias, rememorando: "Eu sou de origem bem humilde, somos em oito irmãos, quatro fizeram dois cursos na Universidade Federal e os outros fizeram supletivo há pouco tempo, de tanto que ficaram reprovados..."; "Nós precisamos potencializar, capacitar e dar condiçóes e tempo para que as pessoas planejem e consigam dar conta"; "Minha mãe mandava a gente para escola, se arrumar, dava um beijinho e falava assim: 'Vai que você vai ser uma menina do bem'. E tenho um irmão meu que nunca quis ir para a escola, que foi para a vida porca, tanto é que tem 12 anos que ele é sumido aí, ninguém sabe o paradeiro. Hoje ela está com 80 anos, ou 81, fala assim: 'Ele não quis ir para a escola, então não virou um cidadão de bem".

No episódio Um raio de Sol através da chuva, no filme Sonhos (1990), os tempos que surgem são tempos de inquietações. Ao encararmos a Imagem 2, somos forçados a nos questionar sobre esse espaço que a criança ocupa no currículo (CARVALHO, 2013) - escondida, alvo de olhares sorrateiros, silenciada? Nascem tempos que nos instigam a perguntar o que é a procissão (tal qual a procissão do casamento das raposas no filme) do currículo na vida das crianças, tempos em que desviamos nossos olhos: será apostar na entrega da lâmina japonesa ou dar indicações de onde podem achar o arco-íris? 
Imagem 2 - Um raio de Sol através da chuva (1990)

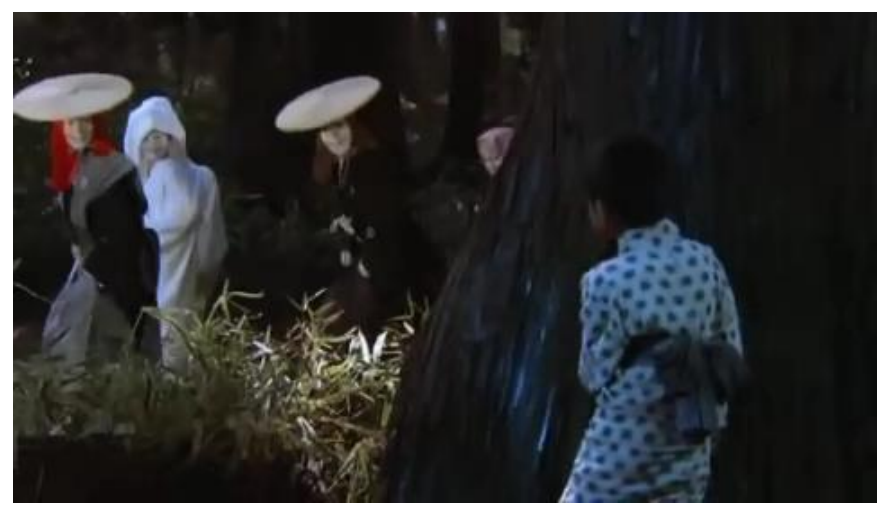

Fonte: Filme Sonhos

Tão desterritorializante quanto o filme de Akira Kurosawa é a obra produzida na École Supérieure des Métiers Artistiques de MontPellier - o curta Frat (2008). "Na questão do filme, eu digo mesmo: se eu pudesse, eu não assistia a esse filme. Me leva a refletir assim: será que eu sou aquela que doa o sangue ou será que sou aquela que pegava o sangue do outro? Como que é isso? Será que eu estou insensível dessa atuação do outro? Do meu aluno?'. Ao fazer esse relato sobre o curta-metragem, a professora nos contou sobre a tristeza que a afligiu com as imagens do filme e, mesmo na aflição de quem não sabe quais papeis ocupa, as vozes que se juntaram a ela contaram da experiência de se fazer docente, de se dedicar, de atravessar tempos tantos - que percorrem outros espaços que não a escola, que se incidem direto na vida. Enfim, o filme que se faz triste fez também buscar outras formas de afirmar: "Eu não me sinto uma professora engessada".

Assim, ao trazermos o curta $O$ vendedor de fumaça (2013), problematizamos esse lugar de não ser um professor engessado - como dissemos, numa das conversas, todo professor é um fazedor de fumaças. Não no sentido de enganar, mas de produzir vida nos corpos que andam encurvados. Professores jovens, radiantes, malabaristas e que, quando não envolvidos nas mirabolantes maneiras de fazer a vida pulsar, podem se permitir ter uma idade qualquer. Discutimos os tempos etários da própria docência! 
Ampliamos as discussões de potência com o filme Somos todos diferentes (2007). As perguntas que surgiram foram sobre os tempos que se fazem possíveis dentro das escolas. Apesar de o filme Somos todos diferentes apresentar teor hollywoodiano - um filme salvacionista, que apresenta um contexto muito surreal em que um professor tem horas infinitas para atendimento especial a um aluno -, os movimentos de criação de outros espaços e de outros tempos e também de outros usos dos tempos institucionalizados provocaram nos professores uma retomada de suas ações, a redescoberta dos tempos de suas próprias práticas. " $Z$., você podia fazer teatro esse ano para nós'. 'Ah, não, gente, teatro este ano não. De novo? Vou... trabalhar com música'. 'Você conhece música?'. 'Não! Vou conhecer. Vou ter uma noção básica e trabalhar com música!" - enfim, o filme provocou no grupo a redescoberta dos tempos que eles inventam cotidianamente, sempre criando outros possíveis.

Imagem 3 - Tanza (2005)

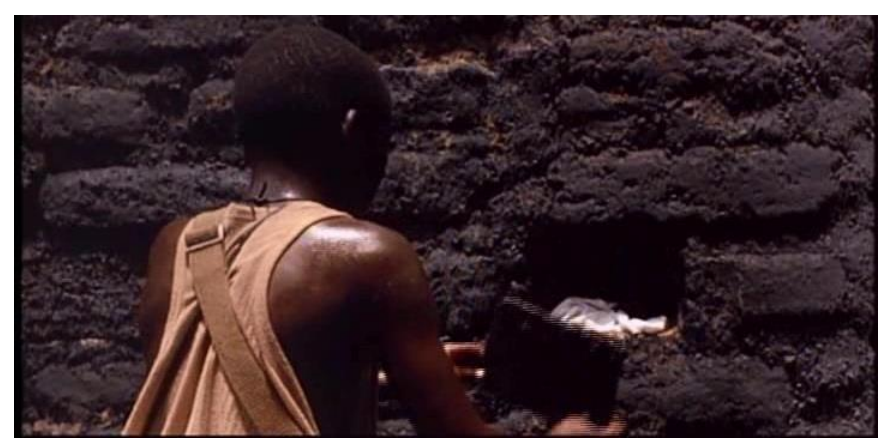

Fonte: Filme Crianças Invisíveis

Em Tanza, o primeiro episódio do filme Crianças invisíveis, os atravessamentos são de estranhamento: como as crianças dão importância à escola? O que significa sentir-se bem na escola? A escola pode ser uma linha de fuga para alguns modos de vida? Ver o garoto Tanza (Imagem 3) tirar um bloco de uma parede de uma casa destruída e encontrar ali, escondido, seus "tesouros" envoltos em um pano muito claro; vê-lo desmitificando o futuro a cada vez que ele imita o barulho de uma bomba... Vemos imagens que são muito fortes, que são outros jeitos de se estar na vida e que, por vezes, encontram nas escolas aquilo que 
elas sonhariam ter. "Eu perguntei o que a escola tem de bom e o que poderia melhorar, porque não podia também queimar a escola, né? É claro que teve resposta no 'O que tem de bom?', tiveram muitas respostas sobre recreio, mas uma coisa que me surpreendeu foi que a maioria colocou: o ensino e os professores". E, assim, professores se confrontam, do mesmo modo que o menino Tanza no filme, com o inesperado afeto que faz com que tempos sejam redescobertos para além dos clichês.

\section{Uma temporalidade outra ou das conversas que espantam relógios}

Existem planos de imanência sustentados por "blocos de espaço-tempo" (GUERÓN, 2011, p. 220) e capturados pelo aparelho sensório-motor, por meio do qual percebemos imagens-movimento distintas: perceptivas, ativas e afetivas, ou seja, imagens-percepção, imagens-ação e imagens-afecção. Assim, uma imagemmovimento, presa ao esquema sensório-motor da ação e reação em frente ao objeto dado subordina o tempo ao movimento e, desse modo, a principal característica do cinema da imagem-movimento vem a ser o aparecimento das imagens seguindo a história da trajetória percorrida pelos personagens dos filmes.

No cinema-moderno, em contraposição ao cinema clássico, a concepção da relação entre passado, presente e futuro é alterada. Para Bergson (2006), o que é atual é sempre um presente. O presente torna-se passado quando um novo presente o substitui. As imagens necessitam dessa passagem do presente para o passado a fim de que novas imagens se apresentem. Acontece que essas imagens que passaram não desapareceram, nem se esconderam nas "gavetas da memória" do senso comum: elas se conservam, difusamente e, em estado latente, virtual, no presente que se apresenta. Desse modo, o passado e o presente estariam simultaneamente ligados, seriam coexistentes. As imagens presentes estariam em estado atual, e as imagens passadas, em estado virtual. O tempo se desdobraria a cada instante em presente e passado - presente que passa e passado que se conserva. Uma nova imagem do tempo que não se configura numa trajetória linear: as imagens-tempo que podem produzir imagens-cristal. 
Quando os professores problematizam a partir das imagens-tempo e das imagens-cristal, eles o fazem de modo especular, ou seja, vendo a imagem atual/virtual dentro da imagem fílmica e vice-versa. A imagem-cristal é a mais instigante das imagens-tempo; a partir dela e de seu jogo de duplos e espelhos, podemos pensar uma das características mais contundentes das imagens: a imagem dentro da imagem ou a imagem no espelho. Neste caso, a imagem é uma máquina de pensar, de pensar possibilidades de inverter o caminho habitual da vida, no caso, dos currículos praticados no cotidiano escolar, buscando renovar a existência e realizar, pelo pensamento problematizado, os tempos produzidos nas escolas, como o agenciamento do desejo de invenção dos currículos praticados no cotidiano escolar, produzindo tempos outros para o currículo em imagens novas, assim como um currículo com novas imagens-tempo.

Quando os professores falam sobre o tempo, os enunciados não têm por causa um sujeito que agiria como sujeito da enunciação, pois o enunciado é o produto de um agenciamento, sempre coletivo, que põe em jogo, em nós e fora de nós, as populações, as multiplicidades, os territórios, os devires, os afetos, os acontecimentos.

Ora, romper com as concepções habitualmente idealistas do desejo implica contestar sua lógica: quando se representa o desejo como a tensão de um sujeito em direção a um objeto. $\mathrm{O}$ desejo não é falta, mas processo, aprendizagem; ele sofre apenas por ser interrompido e não pelo fato de o "objeto" se esquivar cada vez mais. Assim sendo, o desejo se distingue do prazer, pois não busca nem o sofrer, nem encontrar prazer - trata-se de um devir, de uma viagem afetiva (DELEUZE; PARNET, 2004).

Os investimentos afetivos dos professores em torno da problematização dos tempos perdidos rumam em direção a tempos redescobertos e inventivos quando o agenciamento do desejo consegue desestabilizar uma experiência organizada por clichês ou esquemas sensório-motores. Esse desdobramento cristalino do real institui um "circuito interior" em que o atual e seu virtual não cessam de se intercambiar, de correr um atrás do outro, "distintos mas indiscerníveis" (DELEUZE;PARNET, 2004) e é esse circuito que nos encontros com professores 
buscamos potencializar pelas problematizações derivadas de percepção, afecções $e$ ações das imagens-tempo e, nelas, das imagens-cristal

\section{REFERÊNCIAS}

AZAMBUJA, Marcos Adegas de. Henri Bergson e seus conceitos de duração, inteligência e intuição para problematizar a psicologia. In: ENCONTRO NACIONAL DA ASSOCIAÇÃO BRASILEIRA DE PSICOLOGIA SOCIAL, 15., 2009, Maceió. Anais....Maceió: ABPS, 2009.

BERGSON, Henri. Matéria e memória: ensaio sobre a relação do corpo com o espírito. São Paulo: Martins Fontes, 2006.

CARVALHO, Janete Magalhães. Currículos entre imagens, sensações e afecções. In: SEMINÁRIO INTERNACIONAL AS REDES EDUCATIVAS E AS TECNOLOGIAS, 7., 2013, Rio de Janeiro. Anais... Rio de Janeiro: Proped/Uerj, 2013.

CARVALHO, Janete Magalhães. O cotidiano escolar como comunidade de afetos. Petrópolis: DP et Alii, 2009.

COELHO, Jonas Gonçalves. Ser do tempo em Bergson. Interface. Comunicação, Saúde e Educação, v. 8, n. 15, p. 233-246, mar./ago.2004.

DELEUZE, Gilles. Bergsonismo. São Paulo: Editora 34, 2012.

DELEUZE, Gilles. A imagem-movimento. São Paulo: Brasiliense, 1985.

DELEUZE, Gilles. A imagem-tempo. São Paulo: Brasiliense, 1990.

DELEUZE, Gilles, PARNET, Claire. Diálogos. Lisboa: Relógio D’Água, 2004.

GUERÓN, Rodrigo. Da imagem ao clichê e do clichê à imagem: Deleuze, cinema e pensamento. Rio de Janeiro: NAU Editora, 2011.

MACHADO, Roberto. Deleuze, a arte e a filosofia. Rio de Janeiro: Jorge Zahar Ed., 2010.

SCHÖPKE, Regina. Por uma filosofia da diferença: Deleuze, o pensador nômade. São Paulo: EDUSP; Rio de Janeiro: Editora Contraponto, 2004. 